\title{
SAJEST
}

http://dx.doi.org/10.4314/sajest.v4i1.39811

Original Article

Open Access

Received: June 2014 / Accepted: 1 August 2016

Published online: June 2017

\section{A study of the roles, opportunities and challenges of environmental sub-committees (ESCs): A case of Masvingo district, Zimbabwe.}

\author{
W. Mhlanga*, T. Mashavave, S Dzvairo
}

\begin{abstract}
Zimbabwe is committed to the implementation of environmental management strategies that promote the conservation of biological diversity while supporting sustainable utilisation of natural resources. As part of this strategy, Environmental Sub-Committees have been established throughout the country in order to support the work of Environmental Committees. This study was conducted in Masvingo District to determine the role of Environmental Sub-Committees in Natural Resources Management and the challenges they face. Purposive sampling was used to select the respondents in the Wards which had functional committees. Questionnaires were used in interviews with 38 Environmental Sub-Committee members from 12 wards as well as representatives from 8 organisations that interface with Environmental Sub-Committees. The results showed that the major roles of Environmental SubCommittees were related to promoting environmental awareness and in the
\end{abstract}

Wilson Mhlanga* Tafadzwa Mashavave

Department of Environmental Science, Bindura University of Science Education, P. Bag 1020, Bindura, Zimbabwe

E-mail: wlm63@iwayafrica.co.zw

S Dvairo,

Masvingo Rural District Council, P.O. Box, Masvingo, Zimbabwe enforcement of environmental laws. Major challenges faced by Environmental SubCommittees were resistance from the communities, absence of an Environmental sub-Committee identification system and inadequate transport. The majority of the respondents highlighted that there was a need to amend several by-laws in order to enhance environmental protection within the District. The most common offences are related to deforestation (41\%), veld fires $(27 \%)$ and gold panning (12\%). There was a high incidence of repeat offenders and this was attributed to the nondeterrent fines currently in place. It was therefore recommended that Environmental Sub-Committees should strengthen efforts to create awareness of their activities among those stakeholders who are also involved in natural resources management. Environmental Sub-Committees can play a pivotal role in Natural Resources Management if the challenges that they face are fully addressed.

Key words: Environmental Sub-Committees, Masvingo District, Natural Resources Management, Environmental protection, Sustainable Utilisation, Zimbabwe 


\section{Introduction}

Zimbabwe is committed to environmental management and the conservation of biological diversity. Consequently, at the international level, the country is a signatory to several Multilateral Environmental Agreements (MEAs). These include the Convention on Biological Diversity (CBD), (Convention on Biological Diversity, 1992), Convention on International Trade in Endangered Species of Wild Fauna and Flora (CITES, 1973 as amended), Convention on Wetlands of International Importance, especially as waterfowl habitat (Ramsar, 1971), United Nations Framework Convention on Climate Change (1992) (UNFCCC) and the United Nations Convention to Combat Desertification (UNCCD).

At the national level, Zimbabwe's Constitution implicitly recognises the importance of these MEAs. Section 34 of Chapter 2 of the constitution states that "The state must ensure that all international conventions, treaties and agreements to which Zimbabwe is a party are incorporated into domestic law," (Constitution of Zimbabwe, 2013). In line with this Constitutional provision, several Acts of Parliament on the environment have been enacted. The Act that deals with environmental issues is the Environmental Management Act (Chapter 20:27 of 2003). The Act provides for the establishment of an Environmental Management Agency (EMA). This Agency is mandated to implement the provisions of the Act. One of the major objectives of the Act is to provide for the sustainable management of natural resources and the protection of the environment (Environmental Management Act, 2003). Other Acts that support the Environmental Management Act include the Parks and Wildlife Act, Chapter 20:14 (Parks and Wildlife Act, 1996 as amended), Forest Act, Chapter 19:05 which was amended in 2002 (Forest
Act, 2002), Rural District Council Act, Chapter 29:13 (Rural District Council Act, 1993) and the Traditional Leaders Act, Chapter 29:17 (Traditional Leaders Act, 2000).

In Zimbabwe, state land that is communally owned, (Communal Lands), is under the jurisdiction of the local authorities (Rural District Councils). The traditional leaders also have some responsibilities over this land in terms of the Traditional Leaders Act. The Environmental Management Act has provision for the delegation of responsibilities related to environmental issues, to the Rural District Councils (RDCs). Consequently, in communal lands, the Environmental Management Agency works closely with the both the Rural District Councils and the community structures including the Traditional leaders.

In Masvingo District, most of the land is communal land. The problem with communally owned resources is of shared responsibilities which result in lack of accountability. This leads to the reckless and unsustainable exploitation of natural resources (Masiiwa, 2004). To protect the environment from the 'tragedy of the commons' (Murphree, 1997), mechanisms must be put in place for communities to participate in the management of natural resources. In order to assist in the dissemination of environmental information, the Environmental Management Agency has established Environmental Committees (ECs) and Environmental Sub-Committees (ESCs), (www.ema.co.zw).

In terms of the Traditional Leaders Act (2000), the duties of the chief include, inter alia, "ensuring that the land and its natural resources are used and exploited in terms of the law, and in particular, controlling over-cultivation, over-grazing, indiscriminate destruction of flora and fauna, and illegal settlement, and generally preventing the 
degradation, abuse and misuse of land and natural resources in his area." (Traditional Leaders Act, 2000).

In order to ensure that the Chief's duties with respect to natural resources and the environment are incorporated in the activities of the ESCs, the composition of the ESCs includes one Chief or his/her representative. Thus, the composition of an ESCs should adhere to the following guidelines; (a) The Committee shall have not less than 5 and not more than 14 members appointed by the local authority (the Rural District Council), (b) A Chairperson who shall be the Councillor for the Ward, (c) One Chief or his representative and, (d) Any co-opted member who shall be a local resident and should have a proven track record of sustainable management of natural resources. Thus, the establishment of ESCs is meant to enhance a participatory approach to natural resources management. The objective of this study was to assess the roles of ESCs as well as the opportunities and challenges faced by these ESCs in promoting sound natural resource management in Communal Lands. A Case Study approach was used.

\section{Materials and Methods}

\subsection{Study Area}

The study was conducted in Masvingo District in Masvingo Province (Figure 1). The Province is located in Southern Zimbabwe (Figure 1).
Masvingo District has 35 administrative wards and wards, 29 out of 35 wards have Environmental Sub-Committees. The study covered wards 1, 2, 5, $6,7,8,14,23,24,26,31$ and 32 (Figure 1).

\subsection{Data collection}

Purposive systematic sampling was used to select the respondents in the study from wards with functioning ESCs. Ward numbers were written on small pieces of paper and the first 12 selected ward numbers were to be sampled. The 12 sampled ESCs had a total of 38 respondents. The research included 8 different organisations which are involved directly or have some activities involving natural resources management within the District. These organisations were Environmental Management Agency, SAFIRE (Southern Alliance for Indigenous Resources), Forestry Commission, Ministry of Agriculture, Mechanisation and Irrigation Development, Masvingo Rural District Council, Care International, Zimbabwe Republic Police and Madzivanyika High School. The committees were chosen based on various activities carried out in a particular ward which include type of vegetation, land tenure system, economic activities (agriculture, mining), wards which are affected by non-residents of the wards and their activities such as industrialisation resulting in pollution for example wards surrounding Masvingo City. From each committee four respondents who included the chairman (ward councillor), secretary, monitor and any other committee member were selected. 


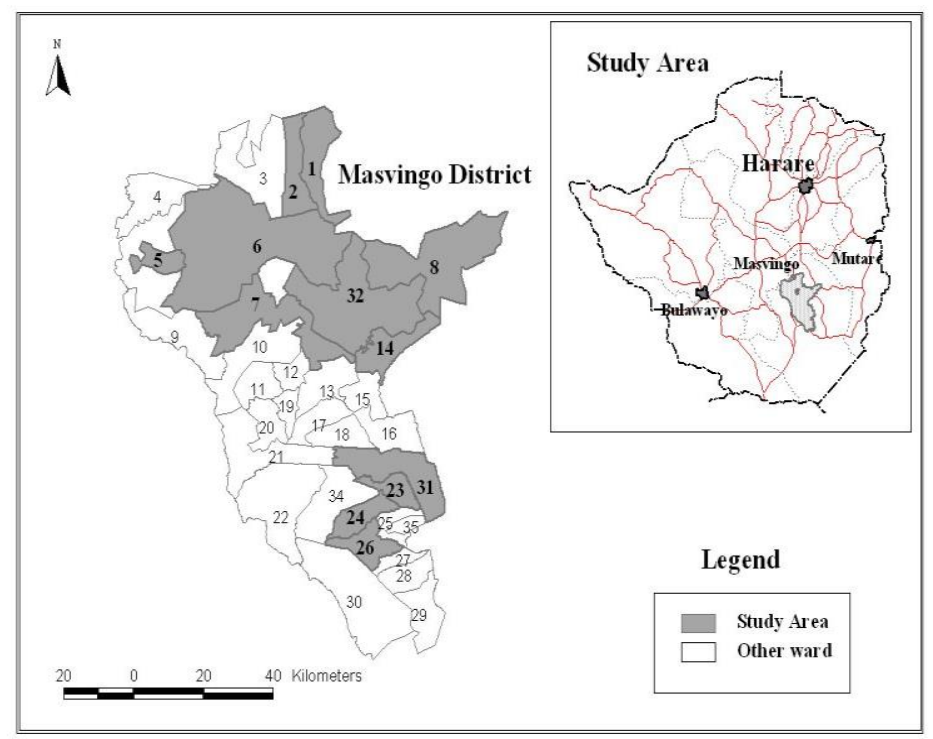

Figure 1: Map showing the study area.

\subsection{Data Analysis}

The data were analysed using Statistical Package for the Social Sciences (SPSS v.17) software. Data were analysed using descriptive statistics to produce tables and graphs.

\section{Results}

A total of 48 questionnaires were administered to the 12 selected ESCs and the response rate was $79 \%$. For organisations, the response rate was $73 \%$.
The average response rate for this research was therefore $76 \%$.

There were $63 \%$ male respondents and $37 \%$ female respondents. On average, $29 \%$ of the respondents were aged between 20 to 40 years, $55 \%$ were aged between 41 and 60 years, while $16 \%$ were aged 61 years and above.

Table 1: Major roles of ESCs as reported by respondents

\begin{tabular}{ll}
\hline Role & Frequency of response \\
\hline Promoting environmental awareness among the public & 25 \\
Enforcing environmental laws & 12 \\
Protecting natural resources & 9 \\
Advising stakeholders on environmental issues & 2 \\
Educating local leaders on environmental issues & 1 \\
Reporting offenders to relevant authorities & 1 \\
Resolving conflicts & 1
\end{tabular}




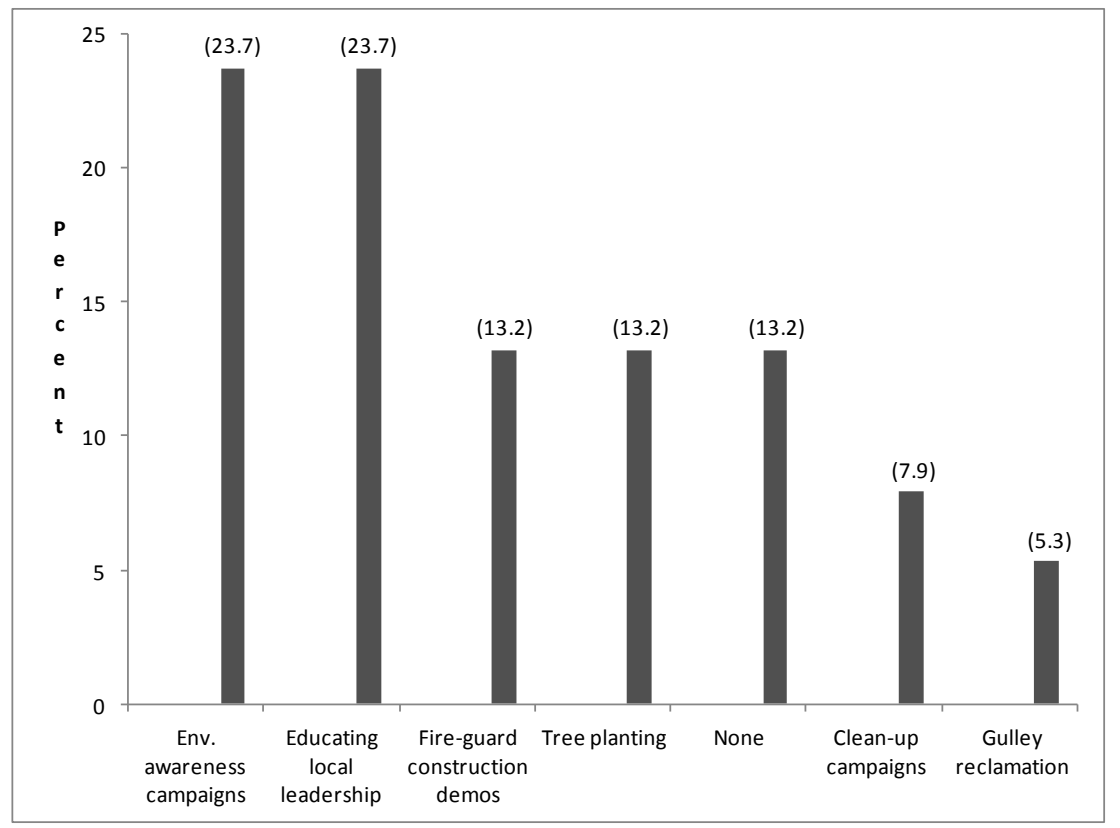

Figure 2: Major activities that are promoted by ESCs

Table 2: Major challenges faced by ESCs

\begin{tabular}{ll}
\hline Challenge faced & Frequency of response \\
\hline Resistance from the community & 18 \\
Lack of ESC Identification systems & 12 \\
Inadequate ESC transport & 7 \\
Conflict with local leadership & 4 \\
Lack of regular funding for ESC activities & 4 \\
Ignorance among stakeholders & 3 \\
Lack of arresting/enforcement powers for ESCs & 2 \\
Politicising of ESC role & 2 \\
Inadequate (soft) penalties for offenders & 1 \\
Lack of ESC meetings & 1 \\
\hline
\end{tabular}

The ESC members promote sustainable natural resources management through various activities that include environmental awareness/education programmes, advisory services as well as enforcing environmental regulations. The ESC members carry out several activities that include tree planting, gulley reclamation carried out by ESCs programmes as well as demonstrating the correct way of constructing fire-guards. All these activities promote environmental protection and sustainable 
natural resource utilisation. The ESCs face several challenges. The major challenges relate to resistance by the community, the lack of an identification system and inadequate transport. Other challenges are related to the lack of arresting powers, and in some cases, the ESC role is politicised where some local leaders may want to bring politics into ESC activities. With respect to the local communities' appreciation of the role of ESCs in natural resources conservation, $55 \%$ of the respondents agreed that the community appreciated the ESC role, $37 \%$ indicated that the communities did not appreciate the ESC role, while $8 \%$ were not sure.

On the issue of the importance of ESCs to improved natural resources management, in their localities, $76 \%$ of the respondents felt that the ESCs were important, while 24\% felt that the ESCs were not important. The majority of the respondents $(63 \%)$ concurred that traditional leaders promoted sustainable natural resources management, while $32 \%$ disagreed and 5\% were not sure. Figure 3 shows the authorities and organisations where the ESC members report offences. The majority of the ESC members report offenders either to the local leaders, or to the Zimbabwe Republic Police (ZRP). A few of the ESC members report offences either to the local offices of EMA (Environmental Management Agency) or to the RDC (Rural District Council).The occurrence of repeat offenders was reported to be high as $71 \%$ of the respondents indicated that they had handled cases of repeat offenders while $29 \%$ of the respondents reported that they had not had such incidences. Deforestation, veld fires and gold panning are the more prevalent offences, while fishing with nets, stream-bank cultivation, use of wooden sledges and tree ring-barking are less prevalent. Most of the ESC members who were interviewed $(87 \%)$ noted that there was a need to amend the Rural District Council by-laws that are focused on environmental management, $10 \%$ of the members stated that there was no need to amend the by-laws, while $3 \%$ were not sure.

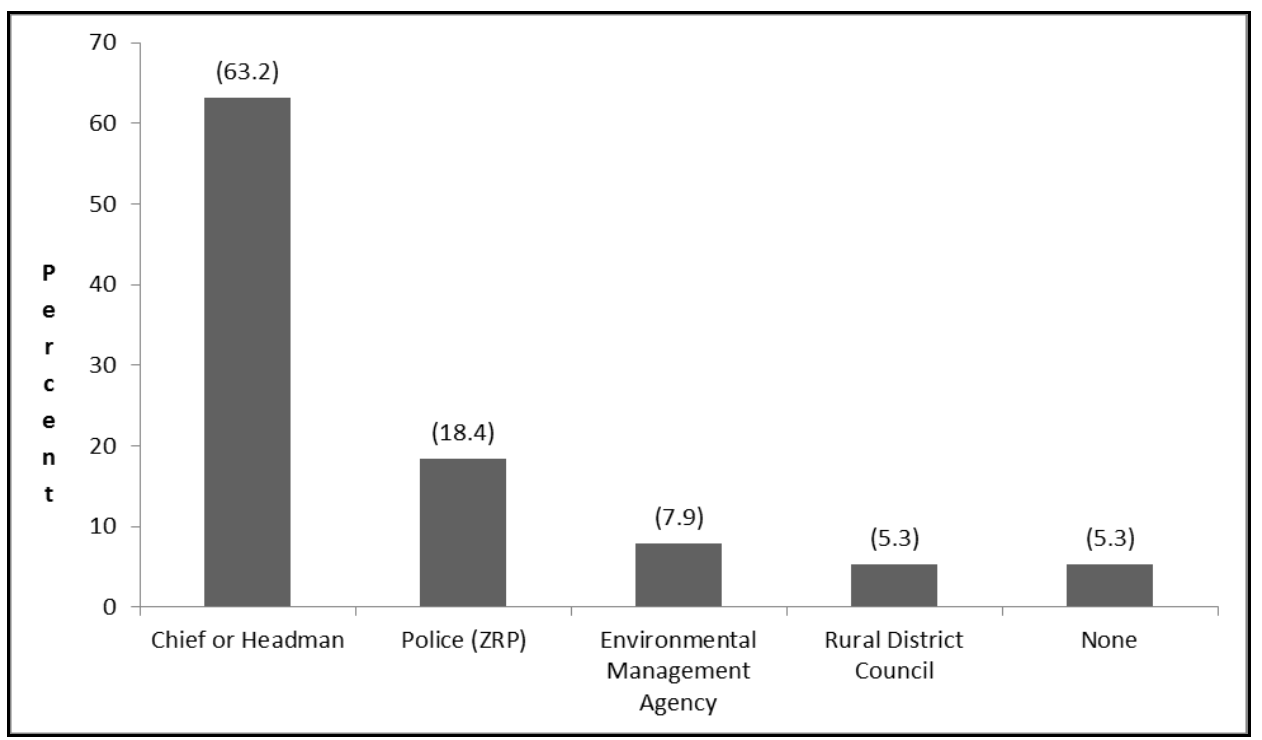


Figure 3. Authorities and organisations where ESCs members can report environmental offences.

Table 3: Common offences reported by ESCs

\begin{tabular}{ll}
\hline Offence & $\%$ \\
\hline Deforestation & 41 \\
Veld Fires & 27 \\
Gold panning & 12 \\
Fishing with nets & 7 \\
Stream-bank cultivation & 5 \\
Use of wooden sledges & 5 \\
Tree ring-barking & 2 \\
\hline
\end{tabular}

Table 4: Recommended amendments to by-laws, as suggested by respondents

\begin{tabular}{ll}
\hline Recommendation & Frequency \\
\hline Fine should be raised & 10 \\
Punishment/Fines for local leadership should be raised & 5 \\
Veld fires & 3 \\
Gold panning & 2 \\
Mine collapsing & 2 \\
Deforestation & 1 \\
Fines should be specific & 1 \\
Number of stock (livestock) kept by each household & 1 \\
Pollution & 1 \\
Sand extraction. & 1 \\
\hline
\end{tabular}

The amendments to the by-laws were to include the increasing of the fines in terms of the penalty fee. It was also recommended that the fines that relate to the local leadership had to be increased as well. More detailed by-laws relating to veld fires, gold panning, mine collapses and deforestation had to be formulated. There was need to formulate by-laws to regulate the number of livestock kept by each household in order to curb overgrazing. By-laws relating to sand extraction and pollution, especially aquatic pollution also had to be revised to make them more stringent. Most of the organisations that were interviewed $(87 \%)$ were aware of the ESCs' activities, and only $13 \%$ were not aware of the activities carried out by the ESCs. Only $63 \%$ of the organisations that were interviewed confirmed that they received reports from the ESCs, while $37 \%$ did not receive any reports.

\section{Discussion}


The results of the study showed that there were more male committee members $(63 \%)$ than female members (37\%) who responded to the questionnaires. The sampling approach was random in terms of gender and hence the differences in the percentages of males and females who responded could be as a result of that there are more males than females in the ESCs. It is worth noting that at least $16 \%$ of the respondents were above 60 years of age. This is important because these individuals have been resident in the area for a long time and they had a lot of institutional memory, especially with respect to environmental issues. The major roles of ESC members' are highlighted in Table 1 . The members indicated that their major roles included promoting environmental awareness among the public, enforcing environmental laws and protecting natural resources. The indicated roles were in line with their mandate as ESC members. As part of their mandate, the ESC members carry out a number of activities which are shown in Figure 2 to promote sound environmental protection and environmental management.

Several challenges are faced by the ESC members. These challenges included resistance by the communities, lack of identification systems, inadequate transport, lack of funding and conflict with the local leadership (traditional leaders). These challenges limit the effectiveness of the ESCs. However, these challenges were not unique to Masvingo District alone as similar problems have been reported by Agrawal and Gibson (1999), Armitage (2005), Pagdee et al. (2006) and Gruber, (2010), With respect to lack of an identification system, some of the ESC members recommended that this could be addressed by either issuing them with identification cards related to their work or providing them with specific clothing (e.g. reflective vests, or uniforms with a specific logo), or both.

The majority of the ESC members felt that local communities appreciated their role in natural resources conservation (Table 6), while $33 \%$ of the members () felt that their role was not appreciated, with only a few $8 \%$ who were not sure. The percentage of members who felt that their role was not appreciated highlights the need to conduct further studies to establish the community members' perceptions of the ESC. Gandiwa et al. (2015) noted that the absence of grassroots institutions and structures for enforcement and management can be a constraint to the enforcement of rules. In the current study, while the devolved structures are in place, in the form of the ESCs, they still lack the legal backing to enforce the rules. Most ESC members (76\%) were of the view that they played an important role in improving natural resources management in their locality. However, $24 \%$ of the respondents felt that the ESCs were not important in improved natural resources management. This negative perception could have been due partly to factors such as lack of powers to arrest /enforce laws and conflicts with local leaders (Table 2). This has been a challenge, especially in the smallholder farming areas where the ESC, together with local leadership were rendered powerless in governing natural resources under their governance by the centralised government system. The same observation was also reported by Chinamatira et. al. (2014).

While $63 \%$ of the ESC members felt that traditional leaders promoted sustainable natural resources management, about one-third (32\%) had a contrary view, while a few $(5 \%)$ were not sure. Conflict with traditional leaders was highlighted as 
one of the challenges (Table 2) and this conflict may have contributed to the perception that traditional leaders did not promote natural resources management. Muchapondwa and Stage (2015) also reported that conflicts may occur between traditional and modern/political structures. They concluded that the disharmony between these structures can reduce the effectiveness of conservation at the local level. Given that almost a third of the ESC members felt that traditional leaders did not promote natural resources management, this lack of implementation has to be explored further through a study that will ascertain in detail the relations and interactions between the Environmental Monitors and the Chiefs and Headmen, especially with respect to natural resources management.

Since the ESC members do not have powers to arrest, they have to report offences to different authorities. Most of the ESC members reported either to the Chief or Headman (63\%). Other members reported to the Police $(18 \%)$, the Environmental Management Agency (EMA) staff and the Rural District Council (5\%). Those who did not make any reports may have been frustrated as a result of the non-deterrent fines which some of the ESC members felt were too lenient (Table 2). The ability to enforce regulations is an important factor in successful Community Based Natural Resources Management (Armitage, 2005; Barrett et al, 2005; Pagdee et al, 2006)

There was a high incidence (71\%) of repeat offenders. The "soft" (lenient) penalties may be a contributory factor as well as the needs of the communities. The common offences are shown in Table 3. The three common offences were deforestation/tree-cutting, veld fires and gold panning. While tree-cutting and gold panning are related directly to meeting livelihood/household needs, the issue of a high incidence of intentional veld fires requires further investigation since this has become a national problem. It is also worth noting that wooden sledges are still in use despite their having been banned. These sledges increase the increase the risk of soil erosion and contribute to deforestation as they are made from trees.

There was concurrence among the majority of ESC members $(87 \%)$ for the need to amend some of the RDC by-laws in order to enhance environmental protection. Details of the proposed amendments are shown in Table 4. There was a strong consensus for increasing the fines so as to make them enough of a deterrent. Other recommendations were also related to strengthening the by-laws so as to enhance environmental protection and improve natural resources management.

The majority of the organisations that were interviewed (87\%) were aware of the ESCs and their activities. Only $13 \%$ were unaware of the ESC activities. The ESC members should make every effort to increase the awareness of their activities among stakeholder organisations through various methods such as visits to the various organisations or through the print media.

The majority of stakeholder organisations (63\%) indicated that they did not receive reports from the ESC. Only a few (37\%) of the stakeholder organisations indicated that they received reports from the ESC. Notwithstanding the financial constraints that the ESCs face, the ESC members should endeavour to inform their major stakeholders using various channels of communication. These can include the traditional reports as well as social media platforms. 


\section{Conclusion}

The findings of this study show that the Environmental Sub-Committees play an important role in environmental protection and natural resources management. However, their effectiveness is hampered by several challenges. Efforts should be made by the relevant stakeholders, to address these challenges so that the ESCs' contribution to the management of the nation's environmental resources is enhanced. These include provision of financial resources to the ESCs as well as facilitating the participation of ESC members whenever these organisations are carrying out activities related to environmental management. Berkes (2004) noted that in community-based conservation initiatives, equity and empowerment are often more important than monetary incentives.

\section{Acknowledgements}

The co-operation of all the ESC members who participated in this study is gratefully acknowledged. The representatives of Environmental Management Agency, SAFIRE (Southern Alliance for Indigenous Resources), Forestry Commission, Ministry of Agriculture, Mechanisation and Irrigation Development, Masvingo Rural District Council, Care International, Zimbabwe Republic Police and Madzivanyika High School who accepted to be interviewed during this study are also acknowledged.

\section{References}

Agrawal, A., Gibson, C.C. 1999. Enchantment and disenchantment: The role of community in natural resource conservation. World Development. 27(4):629-649.
Armitage, D. 2005. Adaptive capacity and community based natural resources management. Environmental Management 35(6):703-715. doi:10.1007/s00267-004-0076-Z

Barrett, C.B., Lee D,R., McPeak J.G. 2005. Institutional arrangements for rural poverty reduction and resource conservation. World Development 33(2):193-197. doi:10.1016/j.worlddev.2004.07.008

Berkes, F. 2004. Rethinking community-based conservation. Conservation Biology. 18(3):621630.

Chinamatira, L., Gwanzura, S., Nyamadzawo, G. (2016) Causes of Veld Fires, Associated SocioEconomic Impacts and Challenges With Policing, in Chakari Resettlement Area, Kadoma, Zimbabwe. Fire Science Reviews 5: doi: 10.1186/s40038-016-0010-5.

Constitution of Zimbabwe. 2013. Government of Zimbabwe. 161 pages.

Environmental Management Act. 2003. Government of Zimbabwe. 45 pages.

Convention on Biological Diversity. 1992. http://www.cbd.int/convention/text.html. Accessed on $10 / 5 / 2013$.

Convention of International Trade in Endangered Species 1973.

http://www.cites.org/eng/disc/text.php.html.

Accessed on 10/5/2013.

Forest Act. 2002. Government of Zimbabwe. Government Printers, 54 p.

Gandiwa, E., Zisadza-Gandiwa, P., Muboko, N., Chibememe, G. 2015. Formal and informal rules in 
the managing the commons. A case study of community based conservation in southern Zimbabwe. $10^{\text {th }}$ Zimbabwe International Research Symposium. Research Council of Zimbabwe. 357368.

Gruber, J.S. 2010. Key principles of communitybased natural resource management: A synthesis and interpretation of identified approaches for managing the commons. Environmental Management. 45:52-66. doi 10.1007/s00267-0089235-y

Masiiwa, M. 2004. Land Reform Programme in Zimbabwe: Disparity Between Policy Design and Implementation. Harare: Institute of Development Studies.

Muchapondwa, E., Stage, J. 2015. Whereto with institutions and governance challenges in African wildlife conservation? Environmental Research Letters. $\quad 10: 1-8 . \quad$ doi:10.1088/17489326/10/9/095013

Murphree M.W. 1997. Articulating voices from the commons, interpretation, translation and facilitation: roles and models for common property scholarship. Society and Natural Resources 10: 415-421.

2013.
Pagdee, A., Kim, Y., Daugherty, P.J. 2006. What makes community forest management successful: A meta-study from community forests throughout the world. Society and Natural Resources. 19:3352. doi: 10.1080/08941920500323260

Parks and Wildlife Act. 1996. Government of Zimbabwe. Government Printers, 54 p.

Ramsar. 1971. Convention on Wetlands of International Importance especially as Waterfowl Habitat. http://www.ramsar.org/. Accessed on 10/5/2013.

Rural District Councils Act. 1993. Government of Zimbabwe. Government Printers, 109 p.

Traditional Leaders Act. (2000). Government of Zimbabwe, Government Printers

United Nations Convention to Combat Desertification. 1994. http://http://www.unccd.int/. Acccessed on 15/5/2013.

United Nations Framework Convention on Climate Change, (1992). Retrieved from the World Wide Web http://unfccc.int/ . Accessed on 15/5/ 